\title{
Evaluation of antioxidant therapy in experimental Chagas disease
}

\author{
Thais de Mello Tieghi ${ }^{[1]}$, Camilla Chimelo Manca ${ }^{[1]}$, Lígia Cangussu Tomaz Garcia ${ }^{[1]}$, \\ Roberto Esteves Pires Castanho ${ }^{[1]}$, Altino Luiz Silva Therezo ${ }^{[2]}$, Fernando Frei ${ }^{[3]}$, \\ Elane de Fátima Taipeiro* ${ }^{* 1]}$ and Luciamáre Perinetti Alves Martins ${ }^{[1]}$
}

\begin{abstract}
[1]. Disciplina de Parasitolgia, Faculdade de Medicina de Marília, Marília, SP, Brasil. [2]. Disciplina de Anatomia Patológica, Faculdade de Medicina de Marília, Marília, SP, Brasil. [3]. Departamento de Biologia, Universidade Estadual Paulista, Assis, SP, Brasil.

[4]. Disciplina de Bioquímica, Faculdade de Medicina de Marília, Marília, SP, Brasil (*in memoriun).
\end{abstract}

\begin{abstract}
Introduction: Stimulation of inflammatory mediators such as cytokines and chemokines may cause oxidative stress in Chagas disease. In this study, we evaluated the merit of vitamins $\mathrm{C}$ and $\mathrm{E}$ as antioxidant therapy to minimize the oxidative stress-induced damage in an experimental model of Chagas disease. Methods: Ninety-six Swiss mice were infected with Trypanosoma cruzi QM2 and treated with vitamins $\mathrm{C}, \mathrm{E}$, or both $(\mathrm{C} / \mathrm{E})$ for 60 and 120 days, and their effects compared to placebo administration were evaluated in the acute and chronic disease phases. Results: There was no difference in parasitemia among treatment groups. However, histological analysis showed more severe inflammation in the skeletal muscle in the vitamin supplementation groups at both the acute and chronic phases. Biochemical analyses during the acute phase showed increased ferric-reducing ability of plasma (FRAP) and glutathione (GSH) levels in the vitamin C and C/E groups. In the chronic phase, a decrease in GSH levels was observed in the vitamin $\mathrm{E}$ group and a decrease in thiobarbituric acid reactive substances (TBARS) was observed in the vitamin C/E group. Moreover, there was a decrease in TBARS in the cardiac tissues of the vitamin $\mathrm{C}$ and $\mathrm{C} / \mathrm{E}$ groups compared to that of the placebo group, although this level was greater in the vitamin $\mathrm{E}$ group than in the vitamin $\mathrm{C}$ group. Conclusions: The antioxidant action of vitamins $\mathrm{C}$ and $\mathrm{E}$ reduced oxidative stress in both the acute and chronic phases of Chagas disease, with a marked effect from joint administration, indicating their inherent synergism.
\end{abstract}

Keywords: Trypanosoma cruzi. TBARS. FRAP. Vitamin C. Vitamin E.

\section{INTRODUCTION}

Chagas disease is an anthropozoonosis caused by the protozoan Trypanosoma cruzi, and is considered one of the most widely distributed diseases in the Americas. According to the World Health Organization ${ }^{1}$, approximately 6 to 7 million people are infected worldwide. Approximately 3 million of these cases occur in Brazil, the bulk of which are chronic cases resulting from previous vector-borne infection. Moreover, the incidence of oral transmission of the pathogen has increased in recent years, which is linked to the consumption of raw contaminated foods, especially in the northern region of the country ${ }^{2}$.

It has been suggested that $T$. cruzi infection increases the formation of reactive oxygen species (ROS) by stimulating inflammatory mediators such as cytokines and chemokines, which then leads to oxidative stress in phagocytic cells ${ }^{3}$. ROS

Corresponding author: Dra. Luciamáre Perinetti Alves Martins.

e-mail: luciamarepam@gmail.com

Received 25 October 2016

Accepted 5 April 2017 and reactive nitrogen species (RNS) have potential to oxidize cellular components such as proteins, lipids, and DNA, leading to morphological deterioration and ultimately cell death in some cases ${ }^{4}$.

The body has several mechanisms to defend against oxidative stress, which work together to terminate the reactions of free radical generation or to remove the reactive species or their secondary products. Antioxidant supplementation is considered to be an asset in the defense against the harm posed by oxidation through ROS and RNS generation ${ }^{5}$. However, some studies contradict this assertion, evincing that excess supplementation may actually be harmful ${ }^{6}$, as it is currently unclear whether oxidative stress is the cause or consequence of the observed injuries 5 .

Although the oxidative stress in Chagas disease is considered a host defense mechanism against parasitemia in the acute phase of infection, studies have demonstrated that it also contributes to the subsequent development of tissue injury ${ }^{4,7}$. In this context, there is some evidence to suggest that vitamin $\mathrm{C}$ and $\mathrm{E}$ antioxidant therapy could be beneficial in minimizing the oxidative stress that occurs over the course of Chagas disease ${ }^{8}$. 
Vitamins $\mathrm{C}$ and $\mathrm{E}$ are compounds obtained from the diet that have high antioxidant power. Vitamin $\mathrm{C}$ is a highly plasmasoluble antioxidant that reduces the number of free electrons in the transition layer, and can therefore prevent biological oxidation ${ }^{9,10}$. Vitamin $\mathrm{E}$ is active in membranes and traps peroxyl radicals, thereby inhibiting lipid peroxidation reactions ${ }^{3,11}$. Numerous studies have shown that these antioxidants, when combined, constitute one of the most effective body defense mechanisms against oxidative stress ${ }^{12-15}$. These antioxidants act in an integrated system wherein the ratio of the concentrations of vitamins $\mathrm{C}$ and $\mathrm{E}$ is of the utmost importance for effective antioxidant protection ${ }^{16}$.

Despite these beneficial effects, few studies have directly examined the relationship between antioxidant therapy and Chagas disease. Therefore, in the present study, we investigated the effects of the supplementation of vitamins C, E, and their combination $(\mathrm{C} / \mathrm{E})$ in the acute and chronic phases of Chagas disease using an animal model of infection. In particular, Swiss mice were infected with the $T$. cruzi QM2 strain, which is known to display high parasitemia and virulence in this mouse line.

\section{METHODS}

\section{Infection of mice and treatment protocol}

Ninety-six male Swiss mice, created in vivarium of the Faculty of Medicine of Marilia with approximately 20 days of age, were intraperitoneally infected with $5.0 \times 10^{4}$ trypomastigote forms of $T$. cruzi QM2 strain ${ }^{17}$ with blood from another previously infected mouse. The mice were randomly assigned to eight groups of 12 mice each, which were divided into groups in the acute phase $\left(\mathrm{PL}_{\mathrm{A}}, \mathrm{VitC}_{\mathrm{A}}, \mathrm{VitE}_{\mathrm{A}}\right.$, and $\mathrm{VitC} /$ $\left.\mathrm{E}_{\mathrm{A}}\right)$ and groups in the chronic phase $\left(\mathrm{PL}_{\mathrm{C}}, \mathrm{VitC}_{\mathrm{C}}, \mathrm{VitE}_{\mathrm{C}}\right.$, and $\left.\mathrm{VitC} / \mathrm{E}_{\mathrm{C}}\right)$. The PL groups received $10 \mu \mathrm{L}$ of mineral water as a placebo; the VitC groups received $500 \mathrm{mg} /$ day vitamin $\mathrm{C}$ only (Cewin ${ }^{\circledR}$ drops - Sanofi Laboratories), equivalent to $7.14 \times 10^{-}$ ${ }^{3} \mathrm{mg} / \mathrm{g}$ weight, diluted in $10 \mu \mathrm{L}$ mineral water; the VitE groups received 800IU vitamin E only (Ephinal ${ }^{\circledR}$ - Bayer Laboratories), equivalent to $11.4 \times 10^{-3} \mathrm{mg} / \mathrm{g}$ weight, diluted in $10 \mu \mathrm{L}$ of mineral oil; and the VitC/E groups received both vitamins $\mathrm{C}$ and $\mathrm{E}$. Administration was performed once a day by pipetting $10 \mu \mathrm{L}$ of the vitamins into the mouths of the mice with a Gilson ${ }^{\circledR}$ pipette.

The groups assessed for acute infection received the treatment for 60 days, whereas the chronic infection groups received the treatment for 120 days. At the end of the acute and chronic phases, all of the animals were euthanized with brief $\mathrm{CO}_{2}$ inhalation $\left(100 \% \mathrm{CO}_{2}\right)^{18,19}$ to facilitate the collection of blood and tissues for analysis.

\section{Ethical considerations}

This study was approved by the Ethics Committee on Animal Research of FAMEMA under protocol no. 1214/12.

\section{Evaluation of parasitemia}

Six animals from each of the four acute groups $\left(\mathrm{PL}_{\mathrm{A}}, \mathrm{VitC}_{\mathrm{A}}\right.$, $\mathrm{VitE}_{\mathrm{A}}$, and $\mathrm{VitC} / \mathrm{E}_{\mathrm{A}}$ ) were randomly selected to study parasitemia in the acute phase. Beginning on the $8^{\text {th }}$ day after infection, measurements were performed twice weekly for 60 days using the Brenner ${ }^{20}$ method adapted by Martins et al. ${ }^{21}$.

\section{Histopathology}

Fragments of the heart, colon, and skeletal muscle from the thigh were collected from all mice and stained with hematoxylin and eosin. For the acute phase evaluation, fragments from the $\mathrm{PL}_{\mathrm{A}}, \mathrm{VitC}_{\mathrm{A}}, \mathrm{VitE}_{\mathrm{A}}$, and $\mathrm{VitC} / \mathrm{E}_{\mathrm{A}}$ groups were collected on the $60^{\text {th }}$ day after infection, whereas fragments from the chronic groups $\left(\mathrm{PL}_{\mathrm{C}}, \mathrm{VitC}_{\mathrm{C}}, \mathrm{VitE} \mathrm{C}_{\mathrm{C}}\right.$, and $\left.\mathrm{VitC} / \mathrm{E}_{\mathrm{C}}\right)$ were collected 120 days after infection. A blind analysis with a semi-quantitative scale of 0 to 3 was used to grade the inflammatory process, and the degree of amastigote nests and necrosis. Scores were defined as follows: 0 , no inflammation, and rare amastigote nests and necrosis; $1(+)$, mild inflammation, and rare amastigote nests and necrosis; $2(++)$, moderate inflammation, and a moderate amount of amastigote nests and necrosis; $3(+++)$, severe inflammation, and abundant amastigote nests and necrosis.

\section{Biochemical analyses}

Blood was collected via cardiac puncture using heparin as an anticoagulant and centrifuged at $3,000 \mathrm{rpm}$ at $4^{\circ} \mathrm{C}$ for 10 minutes. The plasma was separated and aliquots of $200 \mu \mathrm{L}$ were immediately acidified with $800 \mu \mathrm{L}$ of $5 \%$ trichloroacetic acid and frozen for subsequent determination of the ascorbic acid concentration. The remaining plasma and the cardiac and skeletal muscle fragments of each mouse were immediately frozen in liquid nitrogen for the subsequent lipid peroxidation assay.

\section{Ferric-reducing ability of plasma}

The plasma antioxidant capacity was determined using the Ferric-reducing ability of plasma (FRAP) technique described by Benzie and Strain ${ }^{22}$. This technique is based on the plasma's ability to reduce $\mathrm{Fe}+++$ ions to $\mathrm{Fe}++$ in the presence of 2,4,6 tripyridyls-triazine at low $\mathrm{pH}$, which results in the formation of a blue color reading in a spectrophotometer at $593 \mathrm{~nm}$. The antioxidant capacity of each plasma sample was determined by comparing the test absorbance with the absorbance of $\mathrm{Fe}++$ solutions of known concentrations $(100-1,000 \mathrm{mM})$ tested in parallel.

\section{Ascorbic acid contents}

Plasma concentrations of ascorbic acid (i.e., vitamin C) were determined via condensation with 2,4-dinitrophenylhydrazine in the presence of thiourea as reported previously ${ }^{23}$. Readings of the developed colors were performed on a spectrophotometer at $520 \mathrm{~nm}$, and concentrations were determined by comparing the sample's absorbance to a standard curve of ascorbic acid.

\section{Glutathionine contents}

The concentration of erythrocyte glutathionine (GSH) was determined by the colorimetric method developed by Beutler ${ }^{24}$. This method relies on the reduction of 5,5'-dithiobis acid (2-nitrobenzoic acid), which, in the presence of GSH, produces a yellow compound whose optical density is measured at $412 \mathrm{~nm}$. The concentration of GSH was expressed in units of $\mu \mathrm{mmol} / \mathrm{g} \mathrm{Hb}$.

\section{Thiobarbituric acid reactive species contents}

Thiobarbituric acid reactive species (TBARS) levels were measured as biomarkers of lipid peroxidation in the plasma, 
heart tissue, and skeletal muscle using a method adapted from Buege and Aust ${ }^{25}$ and Draper et al. ${ }^{26}$. The TBARS concentrations of each sample were determined by comparing their absorbance with that of a standard malondialdehyde solution.

\section{Statistical analysis}

Two-factor, repeated-measures analysis of variance was used to evaluate the results of the isolated effects of the supplementation of vitamins $\mathrm{C}$ and $\mathrm{E}$ and their combination during the course of parasitemia, with a significance level of $5 \%(\mathrm{p}<0.05)$. Biochemical data measured from the plasma and tissue in the acute and chronic phases were evaluated using parametric variance analysis or, when the assumptions were not met, non-parametric Kruskal-Wallis analysis of variance and assessed at a significance level of $5 \%(\mathrm{p}<0.05)^{27}$.

\section{RESULTS}

\section{Parasitemia}

Evaluation of parasitemia began on the eighth day post-infection, as illustrated in Figure 1, and no significant differences in parasitemia were detected among groups $(p>0.05)$, demonstrating that the different treatments did not change the overall outcome of infection over time. However, the $\mathrm{VitC}_{\mathrm{A}}$ and $\mathrm{VitC} / \mathrm{E}_{\mathrm{A}}$ groups tended to show lower levels of parasitemia than observed in groups $\mathrm{PL}_{\mathrm{A}}$ and $\mathrm{Vit} \mathrm{E}_{\mathrm{A}}$. In particular, the $\mathrm{VitE}_{\mathrm{A}}$ group showed substantial variability throughout the study period, along with the highest peaks in parasitemia of all groups.

\section{Histopathological analysis}

Figure 2 shows representative histological images from Swiss mice infected with $T$. cruzi QM2 strain, which were used for semi-quantitative analysis to determine the extent of inflammation in the two groups. The results of the histopathological analysis conducted in the acute phase are summarized in Table 1. Six animals died during this period: two in the $\mathrm{PL}_{\mathrm{A}}$ group, two in the $\mathrm{VitE}_{\mathrm{A}}$ group, and two in the $\mathrm{VitC} / \mathrm{E}_{\mathrm{A}}$ group. The levels of inflammation were highest in the skeletal muscle fragments, followed by the colon and then the heart. However, these levels were not related to the presence or absence of amastigote nests. All (100\%) of the animals in groups $\mathrm{VitE}_{\mathrm{A}}$ and $\mathrm{VitC} / \mathrm{E}_{\mathrm{A}}$ and $90 \%$ of mice in group $\mathrm{VitC}_{\mathrm{A}}$ showed inflammation in the skeletal muscle. However, the frequency of mice in the $\mathrm{PL}_{\mathrm{A}}$ group with evidence of an inflammatory process in the heart was greater than that in the other groups.

The histopathological factors during the chronic phase are summarized in Table 2. Similar to the acute phase, higher levels of inflammation were found in the skeletal muscle, followed by the colon and then the heart. The severity of inflammation was also more intense in the $\mathrm{VitE} \mathrm{C}_{\mathrm{C}}, \mathrm{VitC} / \mathrm{E}_{\mathrm{C}}$ and $\mathrm{PL}_{\mathrm{C}}$ groups in the skeletal muscle and heart tissue compared to that in the $\mathrm{VitC}_{\mathrm{C}}$ group.

\section{Biochemical analysis}

No statistically significant differences were observed $(p>0.05)$ in plasma ascorbic acid concentrations among groups in the acute phase (Table 3). There was a significant increase in GSH levels in the $\mathrm{VitC} / \mathrm{E}_{\mathrm{A}}$ and $\mathrm{VitE}_{\mathrm{A}}$ groups compared to

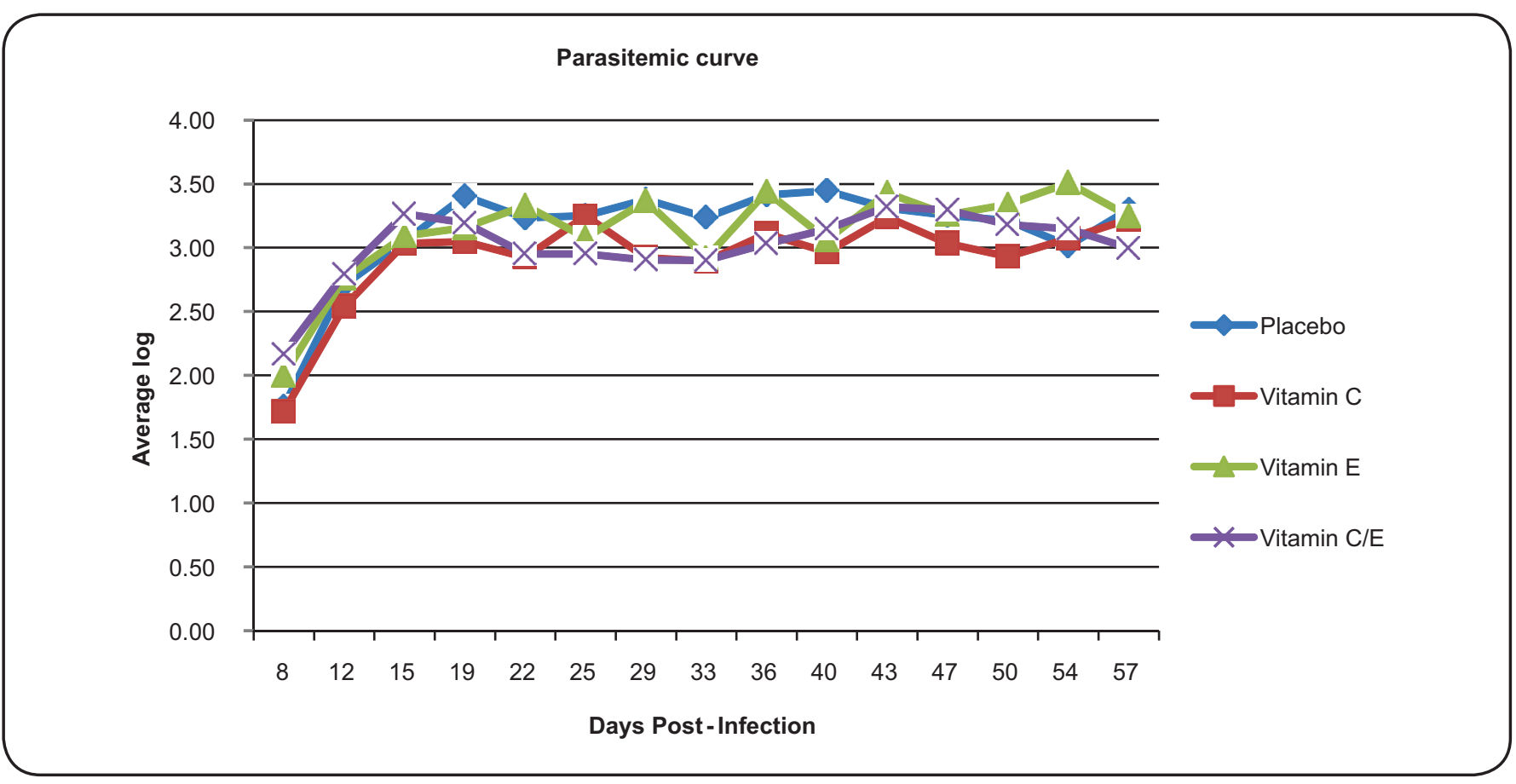

FIGURE 1 - Parasitaemic curve by logarithmic mean of the number of trypomastigotes $/ 5 \mu 1$ of blood - shown in the different experimental groups during the acute phase. 


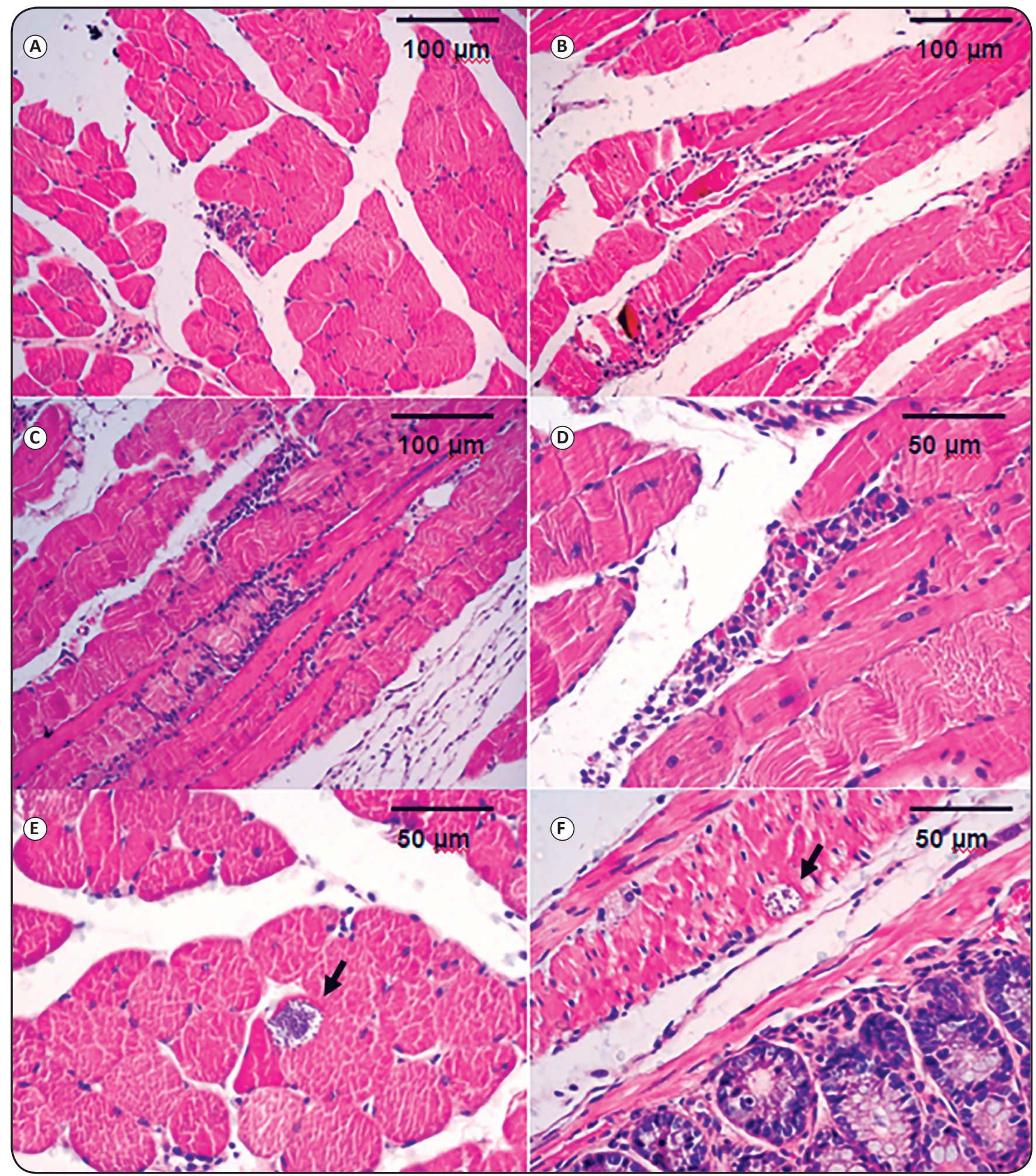

FIGURE 2 - Representative histopathological aspects observed in Swiss mice infected with Trypanosoma cruzi QM2 strain. (A): Mild inflammatory process in the skeletal muscle. (B): Moderate inflammatory process in the skeletal muscle. (C): Severe inflammatory process in the skeletal muscle. (D): Severe inflammatory process with necrosis in the skeletal muscle. (E): Amastigote nest (arrow) in the skeletal muscle. (F): Amastigote nest (arrow) in the colon. 


\section{TABLE 1}

Histopathological analysis of mice during the acute phase of Trypanosoma cruzi QM2 strain infection treated with vitamins or placebo (PL).

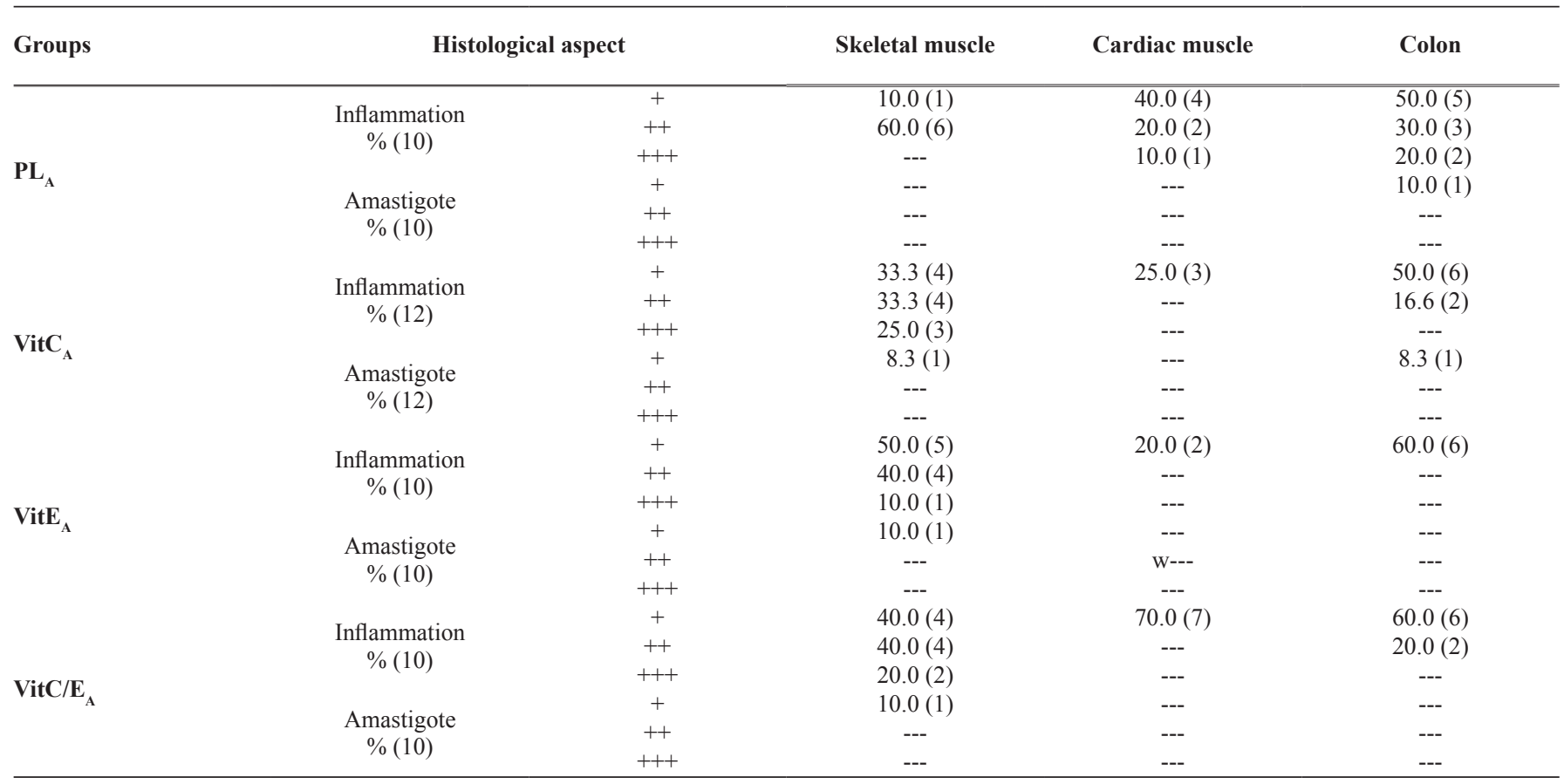

Values are given as the percentage of mice with inflammation or necrosis in each group, and the numbers in parentheses are the absolute number of animals that survived in each group during the study period; the initial infection was performed in 12 animals. $\mathbf{P L}_{\mathrm{A}}$ : animals infected and treated with water in acute phase; VitC $\mathbf{A}_{\mathrm{A}}$ : animals infected and treated with vitamin $\mathrm{C}$ in acute phase; $\mathbf{V i t E}_{\mathbf{A}}$ : animals infected and treated with vitamin $\mathrm{E}$ in acute phase; $\mathbf{V i t C} / \mathbf{E}_{\mathbf{A}}:$ animals infected and treated with vitamin $\mathrm{C}$ and $\mathrm{E}$ in acute phase.

TABLE 2

Histopathological analysis of mice during the chronic phase of Trypanosoma cruzi QM2 strain infection treated with vitamins or placebo (PL).

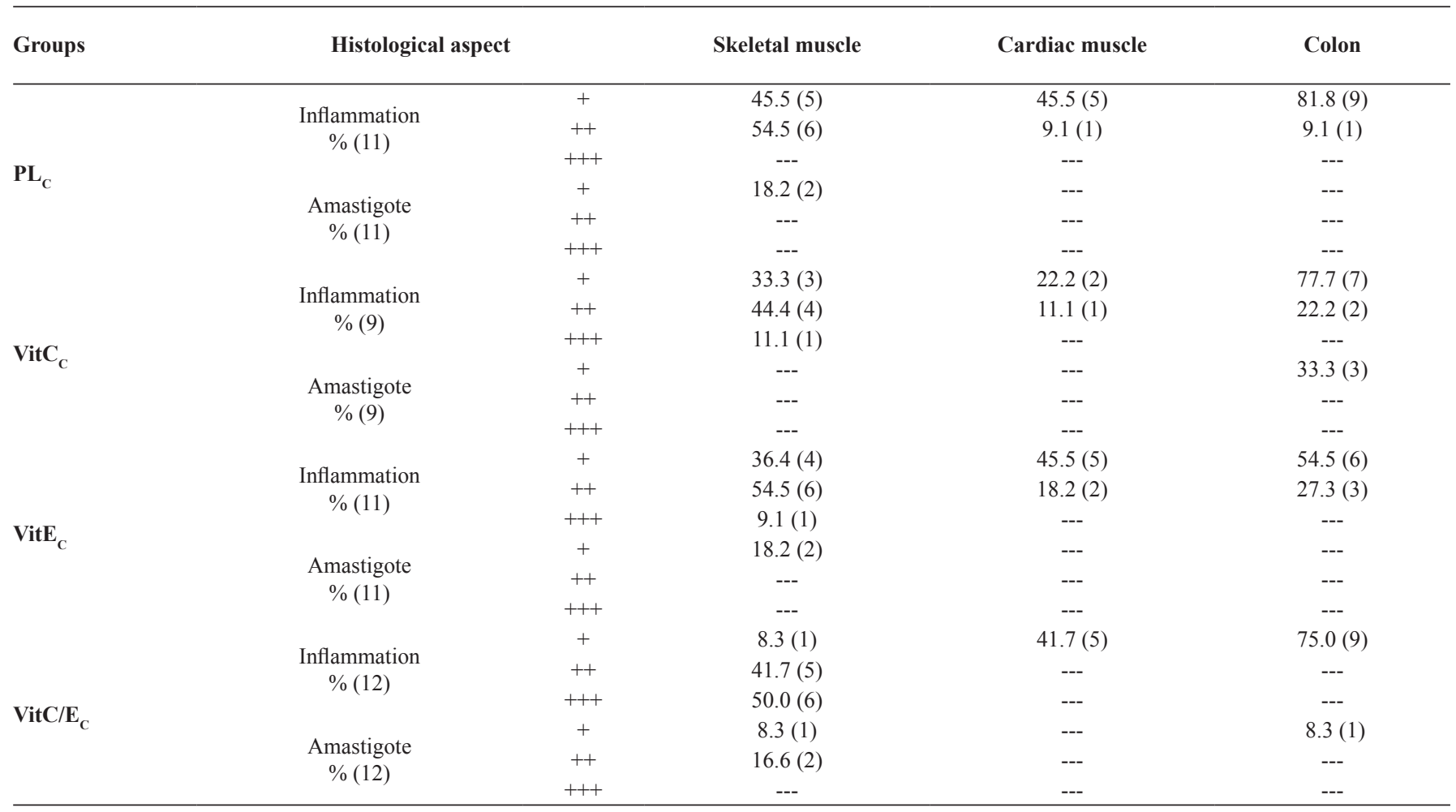

Values are given as the percentage of mice with inflammation or necrosis in each group, and the numbers in parentheses are the absolute number of animals that survived in each group during the study period; the initial infection was performed in 12 animals. $\mathbf{P L}_{\mathbf{C}}$ : animals infected and treated with water in chronic phase; VitC $_{\mathbf{C}}$ : animals infected and treated with vitamin $\mathrm{C}$ in chronic phase; VitE $\mathbf{C}_{\mathbf{C}}$ : animals infected and treated with vitamin $\mathrm{E}$ in chronic phase; VitC/E $\mathbf{E}_{\mathbf{C}}$ animals infected and treated with vitamin $\mathrm{C}$ and $\mathrm{E}$ in chronic phase. 
TABLE 3

Comparison of biochemical parameters determined in the acute phase of Trypanosoma cruzi QM2 strain infection among experimental groups.

\begin{tabular}{|c|c|c|c|c|c|}
\hline & $\mathbf{P L}_{\mathrm{A}}$ & $\mathrm{VitC}_{\mathrm{A}}$ & VitE $_{\mathrm{A}}$ & $\mathrm{VitC} / \mathbf{E}_{\mathrm{A}}$ & Statistical significance \\
\hline \multirow[t]{2}{*}{ Vitamin $\mathrm{C}(\mu \mathrm{M})$} & 20.44 & 20.81 & 22.89 & 22.78 & $p>0.05$ \\
\hline & $(3.24)$ & $(6.82)$ & $(5.28)$ & $(6.38)$ & \\
\hline \multirow{2}{*}{$\begin{array}{l}\text { Relative contribution of } \\
\text { vitamin C to FRAP }(\%)\end{array}$} & 19.23 & 9.16 & 15.21 & 8.11 & $\mathrm{PL}_{\mathrm{A}} \times \mathrm{VitC}_{\mathrm{A}} * *$ \\
\hline & $(4.03)$ & $(4.36)$ & $(7.29)$ & $(3.80)$ & $\mathrm{PL}_{\mathrm{A}} \times \mathrm{VitC} / \mathrm{E}_{\mathrm{A}}^{* *}$ \\
\hline GSH & 7.03 & 6.13 & 9.69 & 10.50 & $\begin{array}{c}\mathrm{VitE}_{\mathrm{A}} \times \mathrm{VitC} / \mathrm{E}_{\mathrm{A}}^{* *} \\
\mathrm{PL}_{\mathrm{A}} \times \mathrm{VitE}_{\mathrm{A}}^{*}\end{array}$ \\
\hline \multirow[t]{2}{*}{$(\mu \mathrm{mol} / \mathrm{g} \mathrm{Hb})$} & $(1.43)$ & $(2.77)$ & $(1.74)$ & $(2.08)$ & $\mathrm{PL}_{\mathrm{A}} \times \mathrm{VitC} / \mathrm{E}_{\mathrm{A}}^{*}$ \\
\hline & & & & & $\mathrm{VitC}_{\mathrm{A}} \times \mathrm{VitE}_{\mathrm{A}}^{*}$ \\
\hline \multirow[t]{3}{*}{$\operatorname{FRAP}(\mu \mathrm{M})$} & 208.9 & 509.10 & 326.5 & 610.97 & $\begin{array}{c}\mathrm{VitC}_{\mathrm{A}} \times \mathrm{VitC} / \mathrm{E}_{\mathrm{A}}^{*} \\
\mathrm{PL}_{\mathrm{A}} \times \mathrm{VitC}_{\mathrm{A}}{ }^{* *}\end{array}$ \\
\hline & $(59.7)$ & $(150.34)$ & $(82.38)$ & $(171.4)$ & $\mathrm{PL}_{\mathrm{A}} \times \mathrm{VitC} / \mathrm{E}_{\mathrm{A}} * *$ \\
\hline & & & & & $\mathrm{VitC}_{\mathrm{A}} \times \mathrm{VitE}_{\mathrm{A}}^{* *}$ \\
\hline \multirow{3}{*}{ Plasma TBARS $(\mu \mathrm{M})$} & & & & & $\mathrm{VitE}_{\mathrm{A}} \times \mathrm{VitC} / \mathrm{E}_{\mathrm{A}} * *$ \\
\hline & 2.67 & 2.81 & 2.56 & 2.93 & \\
\hline & $(0.35)$ & $(2.07)$ & $(0.85)$ & $(0.55)$ & $\mathrm{p}>0.05$ \\
\hline \multirow{2}{*}{$\begin{array}{l}\text { Muscle TBARS }(\mu \mathrm{mol} / \mathrm{g} \\
\text { protein) }\end{array}$} & 2.60 & 2.81 & 4.53 & 3.63 & $\mathrm{PL}_{\mathrm{A}} \times \mathrm{VitE}_{\mathrm{A}} *$ \\
\hline & $(0.95)$ & $(1.11)$ & $(1.39)$ & $(0.92)$ & $\mathrm{VitC}_{\mathrm{A}} \times \mathrm{VitE}_{\mathrm{A}}^{*}$ \\
\hline \multirow{2}{*}{$\begin{array}{l}\text { Heart TBARS }(\mu \mathrm{mol} / \mathrm{g} \\
\text { protein) }\end{array}$} & 5.8 & 5.67 & 6.86 & 7.52 & \\
\hline & $(2.80)$ & $(3.59)$ & $(2.24)$ & (2.4) & $\mathrm{p}>0.05$ \\
\hline
\end{tabular}

Data are means (standard deviations).

${ }^{*} \mathrm{p}<0.05$ ANOVA. ${ }^{*} \mathrm{p} p<0.05$ Kruskal-Wallis test. $\mathbf{P L}_{\mathbf{A}}$ : animals infected and treated with water in acute phase; VitC $\mathbf{A}_{\mathbf{A}}$ : animals infected and treated with vitamin $\mathrm{C}$ in acute phase; $\mathbf{V i t E}_{\mathbf{A}}$ : animals infected and treated with vitamin $\mathrm{E}$ in acute phase; VitC/ $\mathbf{E}_{\mathbf{A}}$ : animals infected and treated with vitamin $\mathrm{C}$ and $\mathrm{E}$ in acute phase. FRAP: Ferric-reducing ability; GSH: Erythrocyte glutathionine; TBARS: Thiobarbituric acid reactive species.

those in the $\mathrm{PL}_{\mathrm{A}}$ and $\mathrm{VitC}_{\mathrm{A}}$ groups. However, there was no significant difference in $\mathrm{GSH}$ levels between the $\mathrm{VitE}_{\mathrm{A}}$ and $\mathrm{VitC} /$ $\mathrm{E}_{\mathrm{A}}$ groups. The FRAP level was increased in the $\mathrm{VitC}_{\mathrm{A}}$ and $\mathrm{VitC} /$ $\mathrm{E}_{\mathrm{A}}$ groups compared to the other groups. There was no difference in the TBARS levels in the blood and heart tissue among the experimental groups $(\mathrm{p}>0.05)$, although the VitEA group showed an increased TBARS level in the skeletal muscle tissue.

In the chronic phase, the $\mathrm{VitE}_{\mathrm{C}}$ group showed a significantly decreased plasma ascorbic acid level compared to that of the $\mathrm{VitC}_{\mathrm{C}}$ group (Table 4), and the ascorbic acid level of the $\mathrm{VitC} /$ $\mathrm{E}_{\mathrm{C}}$ group was significantly higher than that of all other groups. There were decreased levels in the GSH blood concentrations of the $\mathrm{VitE}_{\mathrm{C}}$ group when compared to those of the $\mathrm{VitC}_{\mathrm{C}}$ and $\mathrm{VitC} / \mathrm{E}_{\mathrm{C}}$ groups. The FRAP measurement was significantly lower in the $\mathrm{VitC}_{\mathrm{C}}$ group when compared to that of the $\mathrm{PL}_{\mathrm{C}}$ group.

Plasma TBARS levels were significantly lower in the VitC/ $\mathrm{E}_{\mathrm{C}}$ group compared to those of the $\mathrm{P}_{\mathrm{C}}$ and $\mathrm{VitC}_{\mathrm{C}}$ groups. There were no differences in TBARS levels of the skeletal muscle tissue among groups, whereas this parameter was lower in the cardiac tissues of the $\mathrm{VitC}_{\mathrm{C}}$ and $\mathrm{VitC} / \mathrm{E}_{\mathrm{C}}$ groups when compared to that of the $\mathrm{PL}_{C}$ group, and was higher in the $\mathrm{VitE}_{\mathrm{C}}$ group when compared to that of the $\mathrm{VitC}_{\mathrm{C}}$ group.

\section{DIscussion}

The progression of Chagas disease involves a complex interaction between the host's defenses and the effects of the parasite; in particular, the oxidative stress caused by $T$. cruzi can be a protective mechanism used by the host. However, the increased oxidative damage can also lead to pathophysiological changes that increase in severity along with progression of the disease $^{3}$. In this context, increasing the antioxidant potential of the host's defenses can serve as an intervention strategy for slowing down the progression of Chagas disease.

In this study, there were no differences in the plasma concentrations of vitamin $\mathrm{C}$ among experimental groups in the acute phase of infection. One possibility to explain this lack of an effect is related to the method of administration in our experimental design. Levine et al. ${ }^{28}$ reported the maintenance of 
TABLE 4

Comparison of biochemical parameters determined in the chronic phase of Trypanosoma cruzi QM2 strain infection among experimental groups.

\begin{tabular}{|c|c|c|c|c|c|}
\hline & $\mathbf{P L}_{\mathrm{C}}$ & VitC $_{\mathrm{C}}$ & VitE $_{c}$ & $\mathrm{VitC} / \mathbf{E}_{\mathrm{c}}$ & Statistical significance \\
\hline Vitamin $C(\mu \mathrm{M})$ & $\begin{array}{l}17.21 \\
(2.37)\end{array}$ & $\begin{array}{l}18.27 \\
(2.88)\end{array}$ & $\begin{array}{l}14.56 \\
(2.73)\end{array}$ & $\begin{array}{l}22.96 \\
(3.17)\end{array}$ & $\begin{array}{l}\mathrm{PL}_{\mathrm{C}} \times \mathrm{VitC} / \mathrm{E}_{\mathrm{C}}^{*} \\
\mathrm{VitC}_{\mathrm{C}} \times \mathrm{VitE}_{\mathrm{C}}{ }^{*} \\
\mathrm{VitC}_{\mathrm{C}} \times \mathrm{VitC} / \mathrm{E}_{\mathrm{C}}{ }^{*} \\
\mathrm{VitE}_{\mathrm{C}} \times \mathrm{VitC} / \mathrm{E}_{\mathrm{C}}{ }^{*}\end{array}$ \\
\hline $\operatorname{FRAP}(\mu \mathrm{M})$ & $\begin{array}{l}610.78 \\
(2.37)\end{array}$ & $\begin{array}{l}408.03 \\
(2.88)\end{array}$ & $\begin{array}{l}459.95 \\
(2.73)\end{array}$ & $\begin{array}{l}586.05 \\
(3.17)\end{array}$ & $\mathrm{PL}_{\mathrm{C}} \times \mathrm{VitC}_{\mathrm{C}}^{*}$ \\
\hline $\begin{array}{l}\text { Relative contribution of } \\
\text { vitamin C to FRAP (\%) }\end{array}$ & $\begin{array}{l}6.42 \\
(1.69)\end{array}$ & $\begin{array}{l}8.65 \\
(1.90)\end{array}$ & $\begin{array}{c}6.11 \\
(0.97)\end{array}$ & $\begin{array}{l}8.34 \\
(1.93)\end{array}$ & $\begin{array}{l}\mathrm{VitC}_{\mathrm{C}} \times \mathrm{VitE}_{\mathrm{C}}{ }^{*} \\
\mathrm{VitE}_{\mathrm{C}} \times \mathrm{VitC} / \mathrm{E}_{\mathrm{C}} *\end{array}$ \\
\hline $\begin{array}{l}\mathrm{GSH} \\
(\mu \mathrm{mol} / \mathrm{g} \mathrm{Hb})\end{array}$ & $\begin{array}{l}7.14 \\
(2.53)\end{array}$ & $\begin{array}{l}8.48 \\
(1.21)\end{array}$ & $\begin{array}{l}6.03 \\
(0.90)\end{array}$ & $\begin{array}{l}8.61 \\
(1.67)\end{array}$ & $\begin{array}{l}\mathrm{VitC}_{\mathrm{C}} \times \mathrm{VitE}_{\mathrm{C}}^{* *} \\
\mathrm{VitE}_{\mathrm{C}} \times \mathrm{VitC} / \mathrm{E}_{\mathrm{C}}^{* *}\end{array}$ \\
\hline Plasma TBARS $(\mu \mathrm{M})$ & $\begin{array}{l}20.27 \\
(2.37)\end{array}$ & $\begin{array}{l}19.11 \\
(2.88)\end{array}$ & $\begin{array}{l}16.55 \\
(2.73)\end{array}$ & $\begin{array}{l}11.42 \\
(3.17)\end{array}$ & $\begin{array}{l}\mathrm{PL}_{\mathrm{C}} \times \mathrm{VitC} / \mathrm{E}_{\mathrm{C}}{ }^{*} \\
\mathrm{VitC}_{\mathrm{C}} \times \mathrm{VitC} / \mathrm{E}_{\mathrm{C}}{ }^{*}\end{array}$ \\
\hline $\begin{array}{l}\text { Muscle TBARS ( } \mu \mathrm{mol} / \mathrm{g} \\
\text { protein) }\end{array}$ & $\begin{array}{l}13.34 \\
(4.73)\end{array}$ & $\begin{array}{l}13.89 \\
(9.12)\end{array}$ & $\begin{array}{l}15.63 \\
(5.44)\end{array}$ & $\begin{array}{l}13.03 \\
(5.75)\end{array}$ & $\mathrm{p}>0.05$ \\
\hline $\begin{array}{l}\text { Heart TBARS }(\mu \mathrm{mol} / \mathrm{g} \\
\text { protein) }\end{array}$ & $\begin{array}{l}20.70 \\
(8.81)\end{array}$ & $\begin{array}{l}15.77 \\
(2.89)\end{array}$ & $\begin{array}{l}31.65 \\
(13.8)\end{array}$ & $\begin{array}{l}17.63 \\
(5.20)\end{array}$ & $\begin{array}{l}\mathrm{PL}_{\mathrm{C}} \times \mathrm{VitC}_{\mathrm{C}}^{* *} \\
\mathrm{PL}_{\mathrm{C}} \times \mathrm{VitC} / \mathrm{E}_{\mathrm{C}}^{* *} \\
\mathrm{VitC}_{\mathrm{C}} \times \mathrm{VitE}_{\mathrm{C}}^{* *} \\
\mathrm{VitE} \mathrm{C}_{\mathrm{C}} \times \mathrm{VitC} / \mathrm{E}_{\mathrm{C}}^{* *}\end{array}$ \\
\hline
\end{tabular}

Data are means (standard deviations).

${ }^{*} \mathrm{p}<0.05$ ANOVA; ${ }^{*} \mathrm{p}<0.05$ Kruskal-Wallis test. $\mathbf{P L}_{\mathrm{C}}$ : animals infected and treated with water in chronic phase; VitC $\mathbf{C}_{\mathrm{C}}$ animals infected and treated with vitamin $\mathrm{C}$ in chronic phase; $\mathbf{V i t E}_{\mathbf{C}}$ : animals infected and treated with vitamin $\mathrm{E}$ in chronic phase; $\mathbf{V i t C} / \mathbf{E}_{\mathbf{C}}$ : animals infected and treated with vitamin $\mathrm{C}$ and $\mathrm{E}$ in chronic phase. FRAP: Ferric-reducing ability; GSH: Erythrocyte glutathionine; TBARS: Thiobarbituric acid reactive species.

plasma levels of vitamin $\mathrm{C}$ when using a fractionated dosing schedule at regular intervals of less than $1.5 \mathrm{~h}$. In addition, Benke $^{29}$ showed that the plasma concentration of vitamin $\mathrm{C}$ depends on both the dose and method of administration, reaching a plateau of saturation $3 \mathrm{~h}$ after oral administration of $1 \mathrm{~g}$, and decreasing linearly over $24 \mathrm{~h}$. In our study, the mice were treated with the vitamins or placebo daily at 7:00am and blood was collected for analysis in the afternoon. Therefore, it is possible that the time lag between treatment and blood collection may have resulted in an underestimation of the animals' actual plasma vitamin concentrations throughout most of the day.

However, in contrast to this lack of an effect of supplementation on the plasma vitamin $\mathrm{C}$ level in the acute phase, lower parasitemia levels were detected in the $\mathrm{VitC}_{\mathrm{A}}$ and $\mathrm{VitC} / \mathrm{E}_{\mathrm{A}}$ groups, although these differences were not statistically significant. Marim et al. ${ }^{30}$ also observed a decrease in parasitemia levels when administering a dosage equivalent to $500 \mathrm{mg}$ of vitamin C once daily to mice infected with the T. cruzi QM1 strain.
A possible explanation for this decrease over the course of the acute phase can be attributed to the ability of vitamin $C$ to increase the cytotoxicity of natural killer cell $\mathrm{s}^{31}$, and consequently enhance the production of interferon (IFN)- $\gamma$. Siege ${ }^{32}$ also observed an increase in IFN- $\gamma$ levels when vitamin $\mathrm{C}$ was administered via the drinking water of mice infected with murine leukemia virus. Such an increase in IFN- $\gamma$ stimulates the synthesis of inducible nitric oxide synthase, thereby increasing nitric oxide (NO) production by macrophages ${ }^{33}$, which is essential for the control of parasitemia during the first few weeks of infection ${ }^{34}$.

Although we did not measure the NO concentration in the present study, it can be inferred that vitamin C supplementation indirectly stimulated the production of this RNS in the acute phase of Chagas disease given the observation of increased inflammation in the skeletal muscle of animals supplemented with vitamins $\mathrm{C}$ and $\mathrm{C} / \mathrm{E}$ when compared with the placebo group. This effect is most likely attributed to the fact that NO reacts with the superoxide anion to form the peroxynitrite radical, a substance that is very harmful to the cell membrane ${ }^{35}$. 
Similar to the results of Hamilton et al. ${ }^{16}$, in the present study, supplementation of vitamin $\mathrm{C}$ and both vitamins $\mathrm{C}$ and $\mathrm{E}$ together during the acute phase yielded an increase in the plasma antioxidant capacity. This observation reflects the complex interactions that occur between different components involved in the regulation of plasma antioxidant capacity components to enhance protection against free radicals under certain circumstances $^{21,36}$. Our results indicate that supplementation with vitamin $\mathrm{C}$, an important component of FRAP, could either directly or indirectly stimulate this defense mechanism.

However, supplementation with vitamin $\mathrm{E}$ resulted in an increase in erythrocyte GSH levels in the $\mathrm{VitE}_{\mathrm{A}}$ and $\mathrm{VitC} / \mathrm{E}_{\mathrm{A}}$ groups, suggesting induction of the glutathione synthetase enzyme or other molecules involved in glutathione metabolism, as reported previously ${ }^{37,38}$. Indeed, some studies of Chagas disease $\mathrm{e}^{39,40}$ have shown that one of the host mechanisms in the acute phase of infection involves upregulation of the antioxidant defense system through GSH. This finding suggests that GSH production might constitute a major defense mechanism against oxidative stress in the acute phase of the disease, which would act to maintain the sulfhydryl groups of proteins, eliminate peroxides, and regenerate antioxidant vitamins such as vitamins $\mathrm{C}$ and $\mathrm{E}$.

Despite the positive effect of vitamin supplementation on GSH concentrations, the increases in lipid peroxidation and inflammation in the skeletal muscle observed in the $\mathrm{VitE}_{\mathrm{A}}$ group indicated that supplementation with vitamin E only in the acute phase had an overall deleterious effect on the muscle tissue. Kontush et al. ${ }^{41}$ observed a pro-oxidant effect of $\alpha$-tocopherol when its co-antioxidants were exhausted under conditions of mild oxidation. Therefore, the results of the $\mathrm{VitE}_{\mathrm{A}}$ group in the present study suggest that supplementation of vitamin $\mathrm{E}$ at this stage had a pro-oxidant effect to encourage an imbalance between the concentrations of vitamin $\mathrm{E}$ and its co-antioxidant vitamin $C$. In this way, our results confirm the findings of Witting ${ }^{42}$ and Benzie and $\operatorname{Strain}^{43}$, who demonstrated that vitamins $\mathrm{C}$ and $\mathrm{E}$ operate in an integrated system in which the change in status of a single antioxidant may affect the status of the other. Therefore, the relative proportion of vitamins $\mathrm{C}$ and $\mathrm{E}$ appears to be of the utmost importance in antioxidant protection ${ }^{44}$.

The lack of significant peroxidation in the plasma and heart tissue most likely reflects the relatively powerful antioxidant armory that is present in these parts of the body, making them highly resistant to oxidative stress ${ }^{3,8,43}$. Thus, our results show that antioxidant defense in the plasma and heart muscle was effective in containing the possible oxidative damage arising from the infection. This outcome was found even in group that didn't receive supplementation, in which we observed the lowest values of antioxidant capacity. However, the skeletal muscle has more limited antioxidant defenses than the heart and the blood $^{45}$, corroborating the results observed in this study, where the presence of an inflammatory process was detected in most of the animals in each group at both phases of Chagas disease.

When the infection progressed to the chronic phase, the highest plasma concentration of vitamin $\mathrm{C}$ was found in the
VitC/ $\mathrm{E}_{\mathrm{C}}$ group when compared to levels in the acute phase, and the lowest concentration was found in the $\mathrm{VitE}_{\mathrm{C}}$ group. This indicates a reduction in concentration in the chronic stage, and that only the $\mathrm{VitC} / \mathrm{E}_{\mathrm{C}}$ group maintained levels very close to those found in the acute phase. These findings provide evidence of the cooperative effect conferred by a balanced concentration of these antioxidants, corroborating the findings of several previous in vitro and in vivo experiments ${ }^{8,13-15}$.

More mice in the $\mathrm{VitE}_{\mathrm{C}}$ group showed inflammation in the heart tissue and skeletal muscle compared to the other supplemented groups; however, the inflammation in the skeletal muscle of mice in the $\mathrm{VitC} / \mathrm{E}_{\mathrm{C}}$ group was relatively more intense, ranging from moderate to severe in most of the studied animals.

Nonetheless, the $\mathrm{VitC}_{\mathrm{C}}$ group showed a reduction in total plasma antioxidant capacity, which was the inverse of the effect observed in the acute phase. This finding demonstrated an increase in oxidative stress in this group, which indicates a greater utilization of antioxidant defenses. This suggests that the administration of vitamin $\mathrm{C}$ at high doses with a lower concentration of vitamin $\mathrm{E}$ might promote lipid peroxidation to significantly decrease the animal's antioxidant potential ${ }^{46}$.

By contrast, no antioxidant benefit was observed from vitamin $\mathrm{E}$ supplementation alone in the chronic phase, with no differences compared to the placebo group. In fact, this group even showed a decrease in GSH levels compared to those in the $\mathrm{VitC}_{\mathrm{C}}$ and $\mathrm{VitC} / \mathrm{E}_{\mathrm{C}}$ groups, which is opposite to the effect observed in the acute phase. This demonstrates that an upregulated response $\mathrm{e}^{40}$ of the defense system involving GSH can no longer respond to chronic oxidative stress, which likely reflects depletion of the defense system. This effect is further supported by the increased peroxidation observed in the cardiac tissue of the $\mathrm{VitE}_{\mathrm{C}}$ group as compared to that of the $\mathrm{VitC}_{\mathrm{C}}$ and $\mathrm{VitC} / \mathrm{E}_{\mathrm{C}}$ groups. This finding corroborates evidence obtained by Macao et al ${ }^{8}$, who also observed a decrease in plasma levels of TBARS. Moreover, in the present study, the TBARS levels in the heart were also decreased in the $\mathrm{VitC}_{\mathrm{C}}$ group, demonstrating that under conditions of intense oxidative stress, additional vitamin $\mathrm{C}$ may be required to restore vitamin $\mathrm{E}^{47-49}$ and inhibit lipid peroxidation.

These findings suggest a potentially important role of vitamin $\mathrm{E}$ on the progression of Chagas disease, which requires further studies to elucidate the underlying mechanisms in more detail. This vitamin can inhibit xanthine oxidase ${ }^{50,51}$, and increased activity of this enzyme is involved in inhibiting the proliferation of $T$. cruzi in the sera of infected patients ${ }^{52}$. The intermittent variability of parasitemia observed in the $\mathrm{VitE}_{\mathrm{A}}$ group provides further evidence of the role of vitamin $\mathrm{E}$ in the response to infection.

In summary, we observed a decrease in oxidative stress in both the acute and chronic phases of Chagas disease due to the antioxidant action of vitamins $\mathrm{C}$ and $\mathrm{E}$, and a synergistic effect was detected when the vitamins were co-administered during infection. These results point to a potentially beneficial role of vitamin supplementation to improve the host's antioxidant defense system to control the progression of infection and the course of Chagas disease. However, more studies are needed as 
NO dosage and its action on parasitemia, besides determinations of uric acid, bilirubin and other thiols to clarify how this integration would aid in the antioxidant capacity.

\section{Conflict of interest}

The authors declare that there is no conflict of interest.

\section{Financial support}

This work was supported by a grant from Programa Institucional de Bolsas de Iniciação Científica/ Conselho Nacional de Desenvolvimento Científico e Tecnológico (PIBIC/CNPq).

\section{REFERENCES}

1. World Health Organization. Chagas disease (American trypanosomiasis). Geneve: WHO. 2016. Available in: http://www. who.int/mediacentre/factsheets/fs340/en/.

2. Ministério da Saúde. Secretaria de Vigilância em Saúde. Doença de Chagas aguda no Brasil: série histórica de 2000 a 2013. Bol Epidemiol. 2015;46:1-9.

3. Gupta S, Wen J, Garg NJ. Oxidative stress in Chagas disease. Interdiscip Perspect Infect Dis. 2009;2009: ID 190354.

4. Wen JJ, Vyatkina G, Garg N. Oxidative damage during chagasic cardiomyopathy development: role of mitochondrial oxidant release and inefficient antioxidant defense. Free Radic Biol Med. 2004;37:1821-1833.

5. Kawsar M, Raihana R, Sultana T, Sohel D, Sohaily SI. In-vitro and in-vivo models for antioxidant activity evaluation: a review. Journal of SUB. 2014;5:21-31.

6. Bjelakovic G, Nikolova D, Gluud LL, Simonetti RG, Gluud C. Mortality in randomized trials of antioxidant supplements for primary and secondary prevention systematic review and metaanalysis. JAMA. 2007;297(8):842-57.

7. Zacks MA, Wen JJ, Vyatkina G, Bhatia V, Garg N. An overview of chagasic cardiomyopathy: pathogenic importance of oxidative stress. An Acad Bras Ciênc. 2005;77(4):695-715.

8. Maçao LB, Wilhelm Filho D, Pedrosa RC, Pereira A, Backes P, Torres MA, et al. Antioxidant therapy attenuates oxidative stress in chronic cardiopathy associated with Chagas' disease. Int J Cardiol. 2007;123(1):43-9.

9. Naidu KA. Vitamin C in human health and disease is still a mystery? An overview. J Nutr. 2003;21:2-7.

10. Hediger MA. New view at C. Nat Med. 2002;8(5):445-6.

11. Traber MG, Stevens JF. Vitamins $C$ and E: beneficial effects from a mechanistic perspective. Free Radic Biol Med. 2011;51(5):1000-13.

12. Riley PA. Free radicals in biology: oxidative stress and the effects of ionizing radiation. Int J Radiat Biol. 1994;65(1):27-33.

13. Strain JJ, Mulholland CW. Vitamin C and vitamin E - synergistic interactions in vivo? Emerit I, Chance B, editors. In: Free Radicals and Aging, Switzerland: Birkhauser Verlag; 1992. p. 419-22.

14. Sharma MK, Buettner GR. Interaction of vitamin $C$ and vitamin $E$ during free radical stress in plasma \pm an ESR study. Free Radic Biol Med. 1993;14(6):649-53.

15. Niki E, Noguchi N, Tsuchiharski H, Gotoh N. Interaction among vitamin C, vitamin E and B-carotene. Am J Clin Nutr. 1995;62 (Suppl 6):1322-6.
16. Hamilton IM, Gilmore WS, Benzie IFF, Mulholand CW, Strain JJ. Interactions between vitamins $\mathrm{C}$ and $\mathrm{E}$ in human subjects. Br J Nutr. 2000;84(3):261-7.

17. Martins LPA, Marcili A, Castanho REP, Therezo ALS, Oliveira JCP, Suzuki RB, et al. Rural Triatoma rubrovaria from southern Brazil Harbors Trypanosoma Cruzi of lineage IIc. Am J Trop Med Hyg. 2008;79(3):427-34.

18. Godin DV, Garnett ME. Effects of various anesthetic regimens on tissue antioxidant enzyme activities. Res Commun Chem Pathol Pharmacol. 1994;83(3):93-101.

19. Billert H, Drobnik L. Carbon dioxide and oxidative stress. Nowiny Lekarskie. 2001;70(7):753-62.

20. Brener Z. Contribuição ao estudo da terapeutica experimental da doenca de Chagas. Dissertação. Belo Horizonte: Universidade Federal de Minas Gerais; 1961. 77 p.

21. Martins LPA, Castanho REP, Rosa JA, Silva LC, Godoy CAP, Rosa RM. Caracterização biológica, histopatológica e análise de ácido nucléico de uma cepa Trypanosoma cruzi da região de Marília, SP. Rev Soc Bras Med Trop. 2003;36(1):35-9.

22. Benzie IFF, Strain JJ. The ferric reducing ability of plasma (FRAP) as a measure of "antioxidant power": The FRAP assay. Anal Biochem. 1996;239(1):70-6..

23. Bessey OA. Ascorbic acid. Microchemical methods. In: Vitamin methods. New York: Academic Press; 1960. v. 1, p. 303.

24. Beutler E. Red cell metabolism: a manual of biochemical methods. New York: Grune \& Stratton; 1984. 208 p.

25. Buege JA, Aust SD. Microssomal lipid peroxidation. Methods Enzymol. 1978; 52:302-10.

26. Drapper HH, Squires EJ, Mahmoodi H, Wu J, Agarwal S, Hadley M. A comparative evaluation of thiobarbituric acid methods for the determination of malondialdehyde in biological materials. Free Radic Biol Med. 1993;15(4):353-63.

27. Statistical Package for the Social Sciences (SPSS). IBM Corporation Released 2010. IBM SPSS Statistics for Windows, Version 19.0. Armonk New York: IBM Corporation; 2010.

28. Levine M, Conry-Cantilenat C, Wang Y, Welch RW, Washko $\mathrm{PW}$, Dhariwal KR, et al. Vitamin C pharmacokinetics in healthy volunteers: Evidence for a recommended dietary allowance. Proc Natl Acad Sci USA. 1996;93(8):3704-9.

29. Benke KK. Modelling ascorbic acid level in plasma and its dependence on absorbed dose. J Nutr Environ Med. 1999;18(1):11-2.

30. Marim RG, Gusmão AS, Castanho REP, Deminice R, Therezo ALS, Jordão Júnior AA, et al. Effects of vitamin C supplementation on acute phase Chagas disease in experimentally infected mice with Trypanosoma cruzi QM1 strain. Rev Inst Med Trop S Paulo. 2012;54(3):319-23.

31. Noh H, Ha H, Yu MR, Kang SW, Choi KH, Han DS, et al. High glucose increases inducible $\mathrm{NO}$ production in cultured rat mesangial cells. Nephron. 2002;90:78-85.

32. Siegel BV. Enhanced interferon response to murine leukemia virus by ascorbic acid. Infect Immun. 1974;10(2):409-10.

33. Cunningham AC. Parasitic mechanisms in infection by Leishmania. Exp Mol Pathol. 2002;72(2):132-41.

34. Saeftel M, Fleischer B, Hoerauf A. Stage-dependent role of nitric oxide in control of Trypanosoma cruzi infection. Infect Immun. 2001;69(4):2252-9.

35. Gutierrez FRS, Mineo TWP, Pavanelli WR, Guedes PMM, Silva JS. The effects of nitric oxide on the immune system during Trypanosoma cruzi infection. Mem Inst Oswaldo Cruz. 2009;104(Suppl 1):236-45. 
36. Wong RSY, Radhakrishnan AK. Tocotrienol research: past into present. Nutr Rev. 2012;70(9):483-90.

37. Costagliola C, Iuliano G, Menzione M, Rinaldi E, Vito P, Auricchio G. Effect of vitamin E on glutathione content in red blood cells, aqueous humor and lens of humans and other species. Exp Eye Res. 1986;43(6):905-14.

38. Hu JJ, Roush GC, Buwick M, Dubin N, Mahabir S, Chandiramani $\mathrm{M}$, et al. Effect of dietary supplementation of $\alpha$-tocopherol on plasma glutathione and DNA repair activities. Cancer Epidemiol Biomarkers Prev. 1996;5(4):263-70.

39. Chan AC. Partners in defense, Vitamin C and Vitamin E. Can J Physiol Pharmacol. 1993;71(9):725-31.

40. Wen JJ, Garg N. Oxidative modification of mitochondrial respiratory complexes in response to the stress of Trypanosoma cruzi infection. Free Radic Biol Med. 2004;37(12):2072-81.

41. Kontush A, Finckh B, Karten B, Kohlschutter A, Beisiegel U. Antioxidant and prooxidant activity of a-tocopherol in human plasma and low density lipoprotein. J Lipid Res. 1996;37(7):1436-48.

42. Witting LA. Vitamin E - Do we need it? In: Wolinsky I, Hickson JF, editors. Nutrition and Health. Topics and controversies. Boca Raton: CRC Press; 1995. p. 157-179.

43. Benzie IFF, Strain JJ. Effect of vitamin C supplementation on concentrations of vitamins $\mathrm{C}$ and $\mathrm{E}$ in fasting plasma. Asia Pac J Clin Nutr. 1999;8(3):207-10.

44. Gey KF. Vitamins E plus $\mathrm{C}$ and interacting constituents required for optimal health. A critical and constructive review of epidemiology and supplementation data regarding cardiovascular disease and cancer. Biofactors. 1998;7(1-2):113-74.
45. Venditti P, Di Meo S. Antioxidants, tissue damage, and endurance in trained and untrained young male rats. Arch Biochem Biophys. 1996;331(1):63-8

46. Chen LH. Interaction of vitamin $\mathrm{E}$ and ascorbic acid (review). In vivo. 1989;3(3):199-209.

47. Bruno RS, Ramakrishnan R, Montine TJ, Bray TM, Traber MG. $\alpha$-Tocopherol disappearance is faster in cigarette smokers and is inversely related to their ascorbic acid status. Am J Clin Nutr. 2005;81(1):95-103.

48. Bruno RS, Leonard SW, Atkinson JK, Montine TJ, Ramakrishnan R, Bray TM, et al. Faster vitamin E disappearance in smokers is normalized by vitamin $\mathrm{C}$ supplementation. Free Radic Biol Med. 2006;40(4):689-97.

49. Taylor AW, Bruno RS, Frei B, Traber MG. Benefits of prolonged gradient separation for high-performance liquid chromatographytandem mass spectrometry quantitation of plasma total 15 -series $\mathrm{F}_{2}$-isoprostanes. Anal Biochem. 2006;350(1):41-51.

50. Choc CK. Vitamins and related dietary antioxidants. In: Dreosti IE, editor. Trace elements, micronutrients and free radicals. New Jersey: Humana Press; 1991. p. 129-47.

51. Shaheen AA, Abd-el-Fattah AA, Seif-el-Nasr M. Infuence of verapramil on the eficacy of vitamin $E$ in preventing the ischaemiareperfusion induced biochemical derangement in cerebral cortex of rat. Drug Res 1996;47(7):670-3.

52. Hernandez SM, Kolliker-Frers RA, Sanchez MS, Razzitte G, Brito RD, Fuentes ME, et al. Antiproliferative effect of sera from chagasic patients on Trypanosoma cruzi epimastigotes. Involvement of xanthine oxidase. Acta Trop. 2009;109(3):219-25. 